\title{
TRANSESCRITAS DA EDUCAÇÃO: WOOLF E LISPECTOR
}

\author{
Ademilson Filocreão Veiga ${ }^{1}$ \\ Gilcilene Dias da Costa ${ }^{2}$
}

\begin{abstract}
Resumo: O presente artigo enseja, por meio das obras de Virgínia Woolf e Clarice Lispector, pensar as potências de uma transescrita da educação. $\mathrm{O}$ movimento consiste em colocar a literatura sob o domínio dos afectos e perceptos, criar uma intercessão com a filosofia da diferença e a educação, com os personagens de Lispector e Woolf, aproximando e tensionando sentidos ao contingencial e ao essencial da realidade educacional e literária. Partindo desse ponto, esse estudo busca questionar o que é banalizado como realidade única em educação e literatura, por meio de obras das próprias autoras, que realizam deslocamentos de linguagem e experimentaçôes. Para tanto, alguns autores intercedem nesse percurso, como Deleuze e Guattari (1977), Nascimento (2012), Zordan e Tadeu (2004), Prado (2017). Propomos instigaçóes e experimentaçôes no âmbito educacional, por meio de intercessóes e aproximaçóes entre Lispector e Woolf ao encontro de uma transescrita como estilo ou Diferença, uma escrita livre e de livre trânsito entre as autoras e personagens, com suas linguagens que colidem umas com as outras, em movimentos confluentes de potências de vida na educaçáo.
\end{abstract}

Palavras-chave: Transescritas. Educação. Literatura. Transcriações. Filosofia da Diferença.

\section{EDUCATION TRANS-WRITINGS: WOOLF AND LISPECTOR}

Abstract: This article aims, through the works of Virgínia Woolf and Clarice Lispector, to think about the powers of a trans-writing of education. The movement consists of placing literature under the domain of affects and perceptions, creating an intercession with the philosophy of difference

1 Graduado em Letras - Língua Portuguesa pela UFPA. Mestrando do Programa de Pós-graduação em Educação e Cultura (PPGEDUC/UFPA), bolsista CAPES, sob a orientação da Profa. Dra. Gilcilene Dias da Costa. Integrante do Grupo de Pesquisa ANARKHOS - Micropolíticas, Arte-Performance e Experimentaçôes Literárias na Educação (CNPq/UFPA) E-mail: filocreaoademilson@gmail.com

2 Doutora e Mestra em Educação pela Universidade Federal do Rio Grande do Sul (PPGEDU/ UFRGS). Docente Associado II da Universidade Federal do Pará, Campus Universitário do Tocantins/Cametá, Faculdade de Linguagem. Coordenadora do Programa de Pós-Graduação em Educação e Cultura (PPGEDUC/UFPA). Docente permanente do Programa de Pós-graduação de Doutorado em Educacáa em Rede da Amazônia (PGEDA). Líder do Grupo de Pesquisa ANARKHOS - Micropolíticas, Arte-Performance e Experimentaçôes Literárias na Educação (CNPq/UFPA). E-mail: costagilcilene@gmail.com 
and education, with the characters of Lispector and Woolf, bringing and tending meanings to the contingency and to the essential of educational and literary reality. Starting from this point, this study seeks to question what is trivialized as a unique reality in education and literature, through works by the authors themselves, who carry out language shifts and experiments. To this end, some authors intercede on this path, such as Deleuze and Guattari (1977), Nascimento (2012), Zordan and Tadeu (2004), Prado (2017). We propose instigations and experimentations in the educational scope, through intercessions and approximations between Lispector and Woolf in the encounter of a trans-writing as a style or Difference, a free and free-flowing writing between the authors and characters, with their languages that collide with each other, in confluent movements of life's powers in education.

Keywords: Trans-writings. Education. Literature. Trans-creations. Philosophy of Difference.

\section{Os terceiros de Virgínia e Clarice}

O presente ensaio lítero-filosófico enseja movimentar-se a partir da seguinte indagação: Em que medida e em que sentido as literaturas de Virgínia Woolf e Clarice Lispector compóem uma Transescrita da Educação como estilo ou Diferença? Diferença, a saber, que aqui segue pela via deleuziana da criação, inscrita na obra Diferença e Repetição (2018). Portanto, Diferença cuja noção permite conceber processos de criação do novo, processos de fluxos, movimentos, intensidades, intercessóes ou relaçóes entremeadas com a literatura, a filosofia da diferença, a educação. A literatura, por sua vez, insurge no trabalho como um dos territórios de passagem da Diferença, espaço intersticial pelo qual podemos pensá-la e movimentála em suas potências, sobretudo direcionando-as ao âmbito educacional. Nesse jogo criador, a transescrita ${ }^{3}$ se movimenta como ideia-força, a fim de tornar a escrita livre e de livre trânsito entre as autoras, os personagens, o pensamento, a fabulação, a educação.

"A literatura é a vida, vivendo" (LISPECTOR apud MOSER, 2011, p.150). Temos, nessa citação, a ideia Clariciana da literatura como algo intrínseco à vida. Para Lispector, a literatura é a vida e a vida é a literatura. Ao mesmo tempo em que a literatura expressa uma determinada realidade, seja ela interior ou exterior, a realidade é essencial para a literatura. Não para a chamada "literatura realista", mas como um modo possível para enxergar e indagar as questóes que nos cruzam por meio da linguagem.

Virgínia Woolf, por sua vez, questiona o sentido de realidade que ela, assim como Lispector, era cobrada para inserir em suas obras, ditas como abstratas

3 A vazão desses fluxos de livre escrita se conecta com a Transescrita em transe de Rafael Prado (2017, p. 27): “Transescrita, uma escrita do transe, em certa medida xamânica, isto é, de um momento de crise das esferas produtivas, de alteração, de trânsito, de passagem entre os diferentes registros de linguagem/saber que possibilite pensar e escrever com a literatura e a filosofia, e não necessariamente sobre estas, liberando tráfegos e atravessamentos entre as mesmas: traficar entre os domínios, borrar a partição entre o próprio e o figurado, o legítimo e o ilegítimo, não tendo em vista a indiferenciação, no entanto, o cessar dos sentidos cristalizados (na instigação de Deleuze, o desejo ignora a troca, ele só conhece o roubo)". 
demais. Questionando o que significava dizer que algo era real, observou: "parece algo muito caprichoso, muito incerto - ora encontrável numa estrada poeirenta, ora num recorte de jornal na rua, ora num narciso ao sol" (WOOLF, 2019, p.89). Percebemos que os pensamentos de Woolf e Lispector se esbarram nesse ponto: as duas escritoras tomam o real como algo relativo e incerto, passível de criação.

Sendo assim, a dita realidade como a vemos ou compreendemos pouco impregna, de fato, os campos literários inventivos dessas autoras, pois vai além de um conceito único, segue o curso dimensional dos personagens e dos intercessores que nela operam. Dito isso, podemos dizer que entre Clarice e Virgínia há muitos pontos de coincidência, sobretudo no aspecto criativo, livre, visceral de uma escrita que joga com a vida e a morte, e talvez por isso náo caibam comparaçóes apressadas segundo críticos que apontam existir entre elas um distanciamento num ponto: Virgínia era política "demais", por trazer em seus textos as questóes que a inquietavam sobre a condiçáo das mulheres na sociedade, no que diz respeito à opressão de gênero e sexualidade, propondo, muitas vezes, caminhos subversivos para suas indagaçóes e problematizações. Clarice, por sua vez, era política "de menos", pela característica interior de seu texto, debruçado ao Eu e sua existência. Enquanto Virgínia, que anotou em seu diário que pensar era a sua luta, denunciava problemáticas sociais de seu tempo através dos seus escritos, Clarice chegou a ser tida como autora alienada, sem compromisso com a "realidade" do Brasil, por náo direcionar sua escrita para tal temática. Assim, ela não era "política".

Mas, afinal, o que é ser política? E mais além: existe um só modo de ser política em questáo de arte? Segundo Virgínia, "um escritor tem, assim, necessidade de um terceiro olho cuja função é acudir os outros sentidos quando eles gritam por socorro" (WOOLF, 2015, p.70). O terceiro olho aqui referido nos lembra a terceira perna, a qual Clarice escreve a respeito em $A$ paixão segundo G.H. "As duas pernas que andam, sem mais a terceira que prende (...) uma nova terceira perna que em mim renasce fácil como capim, e a essa perna protetora chamar de uma verdade" (LISPECTOR, 2009, p.09).

Para Virgínia Woolf, o terceiro olho é uma necessidade para quem escreve, no sentido de esse olho acudir quem clama por socorro. Ou seja, de forma que esse terceiro olho seja uma espécie de atenção e sensibilidade para o outro que corre perigo e que não é visto pelos demais olhos. Clarice tem a terceira perna, no romance de $\mathrm{GH}$, como uma prisáo. Algo que nos prende por via da realidade: podem ser as obrigaçóes sociais, os códigos de conduta, as morais coletivas. E, em seguida, fala em ter de fazer renascer uma nova terceira perna: aquela que diz respeito a uma verdade. Clarice, entáo, apresenta a transfiguração da terceira perna como fuga de seu uso regulador. Não uma terceira perna que serve de esteio e é inserida forçadamente, mas a que brota, a que nasce.

Nenhuma vida é própria, idêntica a si mesma, toda vida se torna, muda, transmutando-se em outras formas vitais, num contínuo descontinuar-se a que poderíamos chamar de "desconstruçôes", com ênfase no plural, e que Deleuze chamaria de "fluxo vital". (NASCIMENTO, 2012. p.48) 
Evando Nascimento, no seu Clarice Lispector: uma literatura pensante, observa a literatura de Clarice como o fluxo da vida: múltipla, transmutável. Sendo uma literatura pensante, tanto Lispector quanto Woolf deslocomovem o pensamento da sustentação da terceira perna. Ler Clarice ou Virgínia causa o espanto que nos faz (re) pensar a própria vida. Não estamos seguros. Não estamos confortáveis. Estamos indagando questóes que nos foram colocadas com suposta naturalidade, agora vistas, pela literatura, com o terceiro olho.

Um gato sem rabo. A visão daquele animal inesperado e mutilado atravessando o pátio em passadas suaves modificou, por acaso feliz da inteligência subconsciente, a luz emocional em mim. Foi como se alguém deixasse cair uma sombra (...) Sem dúvida, ao observar o gato cotó parar no meio do gramado, como se também ele questionasse o universo, foi como se faltasse algo, algo parecesse diferente. Mas o que estava faltando, o que parecia diferente? (WOOLF, 2019, p.14).

Virgínia descreve a visão de um gato sem rabo. Visão essa que para ela é inesperada, afinal, não estamos acostumados a ver gatos sem rabos. E, no mínimo, incomum. Percebemos o mundo com o terceiro olho, mas o que falta nele? $\mathrm{O}$ que nos incomoda nas questóes do mundo? Talvez náo possamos expressar táo claramente, mas o incômodo já é alguma resposta. A visão do gato sem rabo faz Woolf questionar o que ela toma como o banal da vida. Ao ver o gato, pensa: Então, falta alguma coisa! Então todos os gatos não são iguais! Há gatos com e sem rabo. Gatos de rua e gatos domésticos! Esse gato torna diferente a sua visão tão acostumada aos outros gatos. "É possível que estejamos adormecidos neste mundo; é possível que haja algum outro que é visível a seres com um sentido que agora nos falta" (WOOLF, 2015, p.14).

Deleuze, em Crítica e Clínica, fala sobre o povo que falta: "escrever por esse povo que falta" (1997, p.15). Assim, a literatura é capaz de nos despertar para o povo que falta. O povo que falta e sua voz pululam por meio da escrita. E nós, como leitores, nos deparamos com essa visão do por vir de um gato sem rabo: vejam! Existe um povo que falta!, exclamamos. A escrita se faz, pois, condição de existência de um povo que falta. "Do que viu e ouviu, o escritor regressa com os olhos vermelhos, com os tímpanos perfurados. Qual saúde bastaria para libertar a vida em toda parte onde esteja aprisionada pelo homem e no homem, pelos organismos e gêneros e no interior deles?" (DELEUZE, 1997, p.14). A escrita liberta, ao menos temporariamente, o ser de seus organismos, quando o coloca em contato com imagens que confrontam seu sentido de realidade. De maneira que realize o oposto: desorganifique-o. Assim, pode ser que voltemos dos livros com os olhos vermelhos e os tímpanos perfurados: o mergulho é profundo e pode nos deixar sem fôlego.

Então escrever é o modo de quem tem a palavra como isca: a palavra pescando o que não é palavra. Quando essa não palavra - a entrelinha - morde a isca, alguma coisa se escreveu. Uma vez que se pescou a entrelinha, poder-se-ia com alívio jogar a palavra fora. Mas aí cessa a analogia: a não palavra, ao morder a isca, incorporou-a. O que salva então é escrever distraidamente. Não quero ter 
a terrível limitação de quem vive apenas do que é passível de fazer sentido. Eu não: quero é uma verdade inventada. (LISPECTOR, 2015, p.15)

A palavra capturada aqui surge como a que nos deparamos com suspeita. Ficamos à espreita da palavra. $\mathrm{O}$ que isso quer dizer? Será que conseguimos alcançar o real sentido do que foi dito? Clarice dava muita importância à entrelinha: a coisa embaixo da própria coisa. Também se percebe a crítica da autora ao que seria "fazer sentido". Lispector foi duramente criticada por "não fazer sentido" e ser hermética. Para ela, porém, esse sentido não se encontrava na superfície da palavra. Era algo que se buscava para além daquilo que se lia, que o leitor teria consigo ou não no momento da experiência da leitura. Tal como a ideia de algo que aparece na ponta da linha e que com cuidado se pode passar à parte exposta da escrita, como demonstra Woolf:

Minuto após minuto, ela oscilou aqui e ali entre os reflexos e as ervas silvestres, ao sabor da água, que a erguia e a afundava, até (vocês conhecem aquele puxãozinho) sentir a súbita consolidação de uma ideia na ponta da linha: então, foi só puxá-la com cautela e expô-la cuidadosamente. (WOOLF, 2019, p.09)

Woolf puxa as palavras das profundezas. Como diz, "compartilhar é nosso dever; mergulhar energicamente e trazer à luz aqueles pensamentos ocultos que são os mais mórbidos; não esconder nada; não fingir nada; se somos ignorantes, dizê-lo" (WOOLF, 2015, p.14). Virgínia e Clarice mergulham nas palavras para tentar desvendar o oculto. E, se não conseguem, não é como uma batalha vencida: é deparar-se com a potência do que não se esperava.

"Levar a língua para o deserto. Servir-se da sintaxe para gritar, dar ao grito uma sintaxe" (DELEUZE \& GUATTARI, 1977, p.40). Tanto Clarice quanto Virgínia levaram a língua para o deserto. Ao despontarem como escritoras, havia uma série de pré-conceitos em relaçáo à uma mulher escrever livros. À época de Virgínia, sob pseudônimos masculinos, as mulheres tinham o "dever" de apenas escrever romances: a chamada literatura para moças. À época de Lispector, a literatura engajada estava em alta: falava-se sobre um Brasil com inúmeros problemas sociais: a fome, a pobreza, entre outros. Clarice e Virgínia elaboraram para si próprias uma linguagem única. Dessa forma, traçaram um novo caminho - um arriscado caminho frente ao que se esperava que uma escritora fizesse.

Deram aos seus gritos uma nova sintaxe. É uma maneira diferente de lutar, de contestar e observar o mundo: enquanto as lutas de Virgínia são mais evidentes, as de Clarice nem sempre aparecem à primeira vista. As lutas de Virgínia em sua literatura se movimentavam por meio de questóes de gênero e sexualidade, de modo a problematizar suas determinaçôes opressoras e subvertê-las, oferecendo, pela via da ficção, rupturas de pensamento ao que se estava normalizado a esse respeito. As lutas de Clarice, por sua vez, gritavam para dentro do $\mathrm{Eu}$, nas veredas do seu interior selvagem e inquieto.

Por exemplo, minha tolerância em relação a mim, como pessoa que escreve, é perdoar eu não saber como me aproximar de um modo "literário" (isto é, 
transformando na veemência da arte) da "coisa social". Desde que me conheço o fato social teve em mim importância maior do que qualquer outro. Muito antes de sentir "arte", senti a beleza profunda da luta. Mas é que tenho um modo simplório de me aproximar do fato social: eu queria era "fazer" alguma coisa, como se escrever não fosse fazer. $\mathrm{O}$ que não consigo é usar escrever para isso, por mais que a incapacidade me doa e me humilhe. O problema de justiça é em mim um sentimento tão óbvio e tão básico que não consigo me surpreender com ele - e, sem me surpreender, não consigo escrever. $\mathrm{E}$ também porque para mim escrever é procurar. $\mathrm{O}$ sentimento de justiça nunca foi procura em mim, nunca chegou a ser descoberta, e o que me espanta é que ele não seja igualmente óbvio em todos. (LISPECTOR apud MOSER, 2011, p.271-272)

Interessante observar o sentimento da luta antes do sentimento da arte na autora. Nota-se a linguagem que se torna impossível: como dizer? Basta dizer? Escrever é fazer? Clarice sente-se de mãos atadas: escrever não é suficiente perante uma realidade táo aterradora e desigual. "Terminei sendo uma pessoa que procura o que profundamente se sente e usa a palavra para que o exprima. É pouco, é muito pouco" (LISPECTOR apud MOSER, 2011, p.70). Isso não quer dizer, porém, que Lispector tenha anulado as questôes sociais das suas obras. Elas lá estão, mas de uma maneira singular.

$A$ hora da estrela (1998), por exemplo, é o que mais se tem de proximidade a uma Clarice engajada, de forma explícita. No entanto, ao longo da sua produção também se evidenciam essas questóes de maneira mais ou menos clara. Como é o caso de $A$ paixáo segundo G.H., que tem como uma de suas questóes o reconhecimento e a desconstrução do olhar de uma mulher de classe social alta em direção a uma realidade que existe para fora de seu eixo.

"E os escritores que mais têm para nos oferecer são, muitas vezes, os que mais violentam os nossos preconceitos" (WOOLF, 2015, p.28). A violência de nossos preconceitos acontece por meio desse caminhar interior que propóem as duas autoras. Desacomodando-nos da linguagem habitual, Lispector e Woolf nos fazem repensar sobre os conceitos de realidade, luta e poéticas de escrita. "Palco de releituras em que explodem refraçóes das verdades de cada um - e pela via das verdades, verossímeis, da própria ficção" (GOTLIB, 2013, p.162). Com a literatura, explodir e implodir nossos conceitos prontos sobre as coisas, em refraçóes que se expandem e se espalham.

\section{Transescritas da Educaçáo com a Diferença}

Como pensar, então, em uma Transescrita da Educação como estilo ou Diferença nos entremeios da literatura de Lispector e Woolf? Como experimentar uma transescrita literária capaz de movimentar instigaçóes a respeito da "mobilidade perpétua do real"? (CORAZZA, 2013, p.23). Se, pela arte literária, as duas autoras movimentam a realidade, esbarrando-a por outros espaços, transescrevendo por outras linhas, também instigamos pensar numa Transescrita da Educaçáo como diferença e estilo, uma livre escrita e de livre trânsito, a saber, aquela em que a suposta 
realidade da educação é desterritorializada, questionada, atravessada e atravessável por outras linhas. Transescrita da Educação como transcriação, no sentido deleuziano de que Corazza (2020) atribui, como movimento potente de criação entre as relaçóes de pensamentos e sentidos na educação, por meio de intensidades singulares e coletivas. Pela via de uma Transescrita da Educaçáo, a literatura é o caminho pelo qual experimentamos a "criação de entre-imagens" (CORAZZA, 2013, p.200), com Lispector e Woolf. Por essa perspectiva de uma Transescrita com a Diferença é que os sentidos deslizam, escapando das determinaçóes molares, perfurando espaços para se movimentar e criar modos outros de viver e educar.

"O opressivo e sufocante era o que podemos chamar de educação negativa, que decreta não o que se pode fazer, e sim o que não se pode fazer" (WOOLF, 2013, p.26). Virgínia destaca a educação pautada no não fazer. A educação que é autoritária, proibitiva. "Uma mãe, por exemplo, só lhe confiaria a educação da filha se ela voltasse para casa como se nada tivesse acontecido e não fizesse nada de excêntrico" (WOOLF, 2013, p.28). Em sua época, as mulheres eram educadas para funçóes do lar: coser, cozinhar, se comportar à mesa. Nada "excêntrico", nas palavras da autora. Para Virgínia, no entanto, era importante não só garantir que mulheres estudassem, mas também assegurar que pudessem pensar e experienciar da maneira como desejassem. Woolf se engajava na busca da equidade de direitos para mulheres e homens. Sendo assim, almejava que ambos tivessem a mesma educação. Para a autora, por meio da escola, as mulheres podiam se desenvolver e terem mais oportunidades. E ia além:

Mas o que é necessário não é apenas a educação. É que as mulheres tenham liberdade de experiência, possam divergir dos homens sem receio e expressar claramente suas diferenças (pois não concordo com Falcão Afável que homens e mulheres sejam iguais); que todas as atividades mentais sejam incentivadas para que sempre exista um núcleo de mulheres que pensem, inventem, imaginem e criem com a mesma liberdade dos homens e, como eles, não precisem recear o ridículo e a condescendência. (WOOLF, 2013, p.23)

Clarice Lispector, por sua vez, em crônica na qual se manifestava publicamente contra as medidas educacionais opressivas do governo militar do ano de 1968, pontuou:

Ser estudante é algo muito sério. É quando os ideais se formam, é quando mais se pensa num meio de ajudar o Brasil. Senhor ministro ou presidente da República, impedir que jovens entrem em universidades é um crime. Perdoe a violência da palavra. Mas é a palavra certa. (LISPECTOR, 2018, p.63)

Precisa e contestadora, Clarice não poupa palavras para se manifestar sobre o que a incomoda. Nesse contexto, questionava o modo como os jovens entravam nas faculdades (por meio de "melhores" notas e a pouca quantidade de vagas, o que alargava distâncias entre aqueles que podiam pagar por melhores formas de estudo e os que não podiam). "Se o senhor soubesse do sacrifício que na maioria das vezes a família inteira faz para que um rapaz realize o seu sonho, o de estudar. Se soubesse da profunda e muitas vezes irreparável desilusão quando entra a palavra 'excedente" 
(LISPECTOR, 2018, p.64). Referindo-se à palavra "excedente", Lispector tensiona o processo meritocrático de se acessar uma faculdade, visto que ele não consegue abranger todas as realidades brasileiras.

Só deixar entrar nas faculdades os que tirarem melhores notas é fugir completamente ao problema. O senhor já foi estudante e sabe que nem sempre os alunos que tiraram as melhores notas terminam sendo os melhores profissionais, os mais capacitados para resolverem na vida real os grandes problemas que existem. E nem sempre quem tira as melhores notas e ocupa uma vaga tem pleno direito a ela. (LISPECTOR, 2018, p.63)

Ser inteligente ou ser "o melhor", então, depende de tirar uma boa nota? Será que os atuais métodos da escola são eficazes? Em carta aberta ao Ministro da Educaçáo da época, Clarice se mostra atenta ao que acontecia no país e, mais do que isso, oferece-se à luta dos estudantes. É por isso que, ao ser indagada sobre o que acha da literatura engajada, responde: "Perguntou-me o que eu achava da literatura engajada. Achei válida. Quis saber se eu me engajaria. Na verdade sinto-me engajada. Tudo o que escrevo está ligado, pelo menos dentro de mim, à realidade em que vivemos" (LISPECTOR, 2018, p.50). Com a escrita, Clarice se sentia presente e atenta em relaçáo ao outro. "O contato com o outro ser através da palavra escrita é uma glória. Se me fosse tirada a palavra pela qual tanto luto, eu teria que dançar ou pintar. Escrever é um divinizador do ser humano" (LISPECTOR, 2018, p.81). Escrever, para a autora, era como entrar em contato com o outro, numa relação de afetar e ser afetado.

"E, no entanto, Jane Austen ficava contente quando uma dobradiça rangia, de modo que pudesse esconder seu manuscrito antes que alguém entrasse" (WOOLF, 2019, p. 57). Virgínia descreve Jane Austen como uma autora que precisava escrever às escondidas, atenta a qualquer movimento para que ninguém percebesse que ela escrevia romances. Imaginemos, então, que Virgínia fizesse o mesmo com sua escrita. Escondida dos críticos, que pediam por mais "realidade" em seus textos, Virgínia escreve atenta aos barulhos do mundo e da subversão.

Liberta dos grilhões (antigos e modernos) do cânon do conhecimento que arrastaram a linguagem a um submundo sombrio, "representativo", "reprodutivo" das verdades produzidas por um Sujeito cujo ardor "racional", "autônomo", "moral" resguardara a alcunha da verdade, as linguagens aqui evocadas se erguem como potência criadora e transfiguradora para ativamente produzir, fabricar, inventar, dissimilar, falsear, deslocar, adiar sentidos, proliferar discursos dos quais fala ou silencia. (COSTA, 2016, p. 112)

Imaginemos um encontro entre as duas autoras. Eis que Clarice invade a sala de Virgínia. Virgínia olha para trás, abismada com as feições de loba de Clarice. Mas, inesperadamente, Virgínia náo teme Clarice a ponto de desejar ocultar o que escreve. Lispector invade o teto todo de Virgínia e Woolf a hospeda em seu espaço. As duas se abrigam. As duas se acolhem. E diferente para Clarice aquele espaço. Para Woolf, o espaço inusitado é a própria Clarice. Elas se encaram pela primeira vez. Há um fogo reconhecível nos olhos de ambas que as tornam aliadas. 
Entra-se no cômodo - mas os recursos da língua inglesa seriam estendidos ao máximo, e revoadas inteiras de palavras teriam de existir forçando ilogicamente com as asas o caminho da existência antes que uma mulher pudesse descrever o que acontece quando ela entra num cômodo. Os cômodos diferem tão completamente! São calmos ou estrondosos; abrem-se para o mar, ou, ao contrário, dão para um pátio de prisão; são cheios de roupa lavada pendurada, ou transbordantes de opalas e sedas; são duros como a crina do cavalo ou macios como plumas - basta que entremos em qualquer cômodo (WOOLF, 2019, p.72)

Habitar outros espaços por alianças, onde se percebe como são singulares, como são múltiplos os modos de viver das pessoas. Basta que estejamos dispostos a abrigar e entrar. "Para começar, devemos nos sentar no banco dos réus e não na poltrona do juiz" (WOOLF, 2015, p.27). Sendo assim, essas entradas livres de julgamentos são essenciais para ver e compreender o outro pela via de sua própria singularidade.

Quais espaços o outro habita? Como? Um dos modos de existir e habitar é por meio da linguagem. Temos de pensar que, para muitas pessoas, esse existir na linguagem é impossibilitado.

Eu tenho à medida que designo - e este é o esplendor de se ter uma linguagem. Mas eu tenho muito mais à medida que não consigo designar. A realidade é a matéria-prima, a linguagem é o modo como vou buscá-la - e como não acho. Mas é do buscar e não achar que nasce o que eu não conhecia, e que instantaneamente reconheço. A linguagem é o meu esforço humano. Por destino tenho que ir buscar e por destino volto com as mãos vazias. Mas volto com o indizível. O indizível só me poderá ser dado através do fracasso de minha linguagem. Só quando falha a construção, é que obtenho o que ela não conseguiu. (LISPECTOR, 2009, p.153)

Pela linguagem, busca-se a realidade. E, assim também, indagá-la, e por meio dela, ocupar nosso espaço, resistir. Entre Clarice e Virgínia, a composição autêntica da linguagem é essencial para que seus espaços sejam habitados. Por meio dessa linguagem é que podem arrumar, desarrumar, acessar os cantos, quebrar as paredes, perceber rachaduras.

"A força da não compreensão, própria ao chamado, nada tem a ver com um irracionalismo obscurantista, mas com o inaudito e o não repertoriado, ou o irreconhecível, que só a experiência da intertroca permite" (NASCIMENTO, 2012, p.40). A intertroca, termo mencionado por Nascimento, é o interrelacionar de Lispector e Woolf, por meio do qual se pensa em literaturas e realidades, literaturas e lutas, literaturas e verdades, literaturas e educaçóes.

A intertroca entre Woolf e Lispector acontece, sobretudo, quando náo se busca falar de um único modo, mas se lançar ao que se diz de múltiplo e potente. Uma, como se denomina aqui, transescrita. Buscar, nos rastros de Clarice e Virgínia, uma transescrita literária, por meio de "colisōes com os textos" (CORAZZA, 2020, p.25), através das quais podemos movimentar-nos para pensar em uma Transescrita da Educação com a Diferença. 
Os textos de Woolf e Lispector esbarram-se um com o outro, em colisões que relevam-ocultam fragmentos minoritários de pensamento. Estes que, por sua vez, contagiam reflexóes sobre uma Educaçáo Transcriadora, na qual podemos transescrever linhas de fuga por seus movimentos, intensidades, fluxos de vida e de sentidos.

Transescrita é uma escrita que se relaciona com a outra. Que circunda, transversaliza e contamina-se da outra, invade-a, fica em estado de transe. Um transe que após o contato com o diferente, revisita suas percepçóes.

O transe é um estado de passagem que envolve a criaçáo de um corpo sem órgãos, topos para o tráfego de intensidades. $\mathrm{Na}$ medida em que se deixa atravessar pela estranheza de um elemento extrínseco que o leva a experimentar o caos, o transe implica numa espécie de afirmação da morte. (...) Provoca a ultrapassagem de limiares e cujo propósito é aumentar a vontade de potência. (TADEU, CORAZZA, ZORDAN, 2004, p.27, grifo dos autores).

Como caminhar por meio de uma escrita em transe na literatura e na educação? Como entrar em contato com tal escrita? Por conseguinte, segundo os autores anteriormente citados, uma escrita em transe passa pela criação de um corpo sem órgáos (DELEUZE, 1995) que, por sua vez, é terreno por meio do qual as intensidades caminham e se cruzam. Atravessados pelas imagens de Clarice e Virgínia, somos desacomodados de nossas certezas. Nosso corpo, até então organificado, em suposta ordem, nossos olhos já acostumados, nossos sentidos adormecidos em comodidade... Até que a literatura cause o transe: o estado em que queremos borrar as fronteiras, potencializar-se, ver com mais olhos, criar nascimentos.

"O corpo sem órgãos é, pois, a desterritorialização absoluta. A despossessão, a despersonalização, a dessubjetivação absoluta. Nenhuma organização. Nenhuma hierarquia. Nenhuma estrutura. Pura multiplicidade" (TADEU, CORAZZA, ZORDAN, 2004, p.94). Assim, a transescrita é a expressáo de um corpo sem órgãos, que está se desfazendo da matéria pronta para se abrir à multiplicidade, à diferença, aos riscos do por vir. Não se trata de matéria e forma e sim de compor afectos e intensidades por meio dessas escrituras.

Tal qual um artesão, que no seu processo de coser o tecido da escrita, percorre-o por tentativas, descobertas, rasgos, asperezas, multiplicidades. Esse tecido não é uniforme, não é liso. Faz-se como um espaço de singularidades em potência por sua Diferença, entrelaçando-se, afastando-se.

O transe, prática envolvida na libertação de devires estranhos, avizinha a arte da loucura. Paradoxalmente, também concentra as potências curadoras desencadeadas pelas artes dos deuses que manifestam. Mais do que a vontade dos deuses e imprimir suas intensidades, o transe desorganiza a ordem dos organismos e das estratificaçôes. Entrar em transe é partir para outro plano, mudar de paisagem, viajar. Trata-se de uma abertura a variaçóes microfísicas que propiciam a passagem dos devires e incitam sensaçôes moleculares imperceptíveis aos estados de vigília. (TADEU, CORAZZA, ZORDAN, 2004, p.28-29). 
As transescritas de Virgínia Woolf e Clarice Lispector, ao desorganizarem a ordem das estratificaçóes literárias de seu tempo, póem os leitores em abertura de devires, pelo enfrentamento da arte da escritura e suas perturbaçóes. No estado de transe, náo estamos como que anestesiados ou fora da realidade. Estamos experimentando realidades outras, transitando para fora do nosso olhar e transcriando por esse viés. Observando e atentando-se ao outro, na sua Diferença. "O menor é o que está do lado de fora. Não é necessariamente excluído, mas localizado fora das imagens das quais se valem as maiorias" (TADEU, CORAZZA, ZORDAN, 2004, p.14).

As transescritas da educação propostas por esse trabalho são advindas de movimentos minoritários de um escrever com a diferença. Uma língua menor de um povo menor, a escrever minoritariamente a educação. "A operação poética da escrita alcança, por assim dizer, o político e o coletivo do pensar, mediante um processo de desterritorializaçâo da linguagem. Ela inventa um estilo ou uma minoração na própria língua, a qual Deleuze e Guattari denominaram 'literatura menor" (COSTA, 2016, p. 113). O que dizer de uma educação que transcria em transe? Tal educação é uma força de multidão, força coletiva composta, decomposta e recomposta, como o longo tecido estriado ao qual dedica-se o artesão. Educaçáo que percorre outros planos e potencializa a Diferença como devir.

"Permitimos as estranhezas, idiossincrasias, variações, não-inflexôes, nãosaberes e não-quereres de cada texto. Ainda mais que cada texto possui, carrega e carreia suas próprias aporias, impasses, nós cegos, pontas desatadas" (CORAZZA, 2020, p.24). Transcriar uma escola pela estranheza, pelos impasses, pelas pontas sem lugar. Diferenciando-se da imagem maioritária, única e hegemônica de Escola, essa Transescrita da Educação em transe encontra resistência nas multiplicidades que a realizam.

"O menor se exprime na multidão e funciona como força subterrânea, cheia de fluxos contraditórios e divergentes, que proliferam e desafiam a imposição de um só dogma, de uma só imagem para a verdade" (TADEU, CORAZZA E ZORDAN, 2004, p.15). As forças subterrâneas e contraditórias dos devires cosem pensamentos outros por meio das transescritas. De que maneira? Como agulhas que furam os dogmas escolares com suas próprias verdades e singularidades. Como pontos móveis que unem as singulares maneiras de existir para compor um tecido de multiplicidades, não de maneira homogeneizadora, mas potencializadora.

Quando pensamos numa Clarice que invade a sala de Virgínia e não a amedronta, mas sim a estimula, ou, inversamente, numa Virgínia que se alia a Clarice, significa que tais movimentos se realizam como "intensidades moleculares junto às quais as paisagens se compóem" (TADEU, CORAZZA, ZORDAN, 2004, p.14). As dissemelhanças de Virgínia não a excluem de experimentar Clarice, e viceversa.

Aqui projetamos a ideia de um quarto labiríntico, despojado do "eu" como posse, desprovido de possíveis saídas, em cuja arte é capaz de transfigurar os espaços quebrando paredes e abrindo pontes para a relação eu-outro. A 
imagem labiríntica de quarto recusa a linha reta ao pensar, recusa os espelhos e seus rebatimentos, recusa lugares fixos para habitar, ao contrário disso, instaura a mobilidade, a pluralidade, as misturas, os deslocamentos desse vaguear a ermo pelo quarto do mundo, da imaginação; no quarto estranho povoa um universo de intensidades e forças, encontros e afecçóes, silêncios e reverberaçóes, signos circundam por entre-lugares de uma poética gestada no dorso da Diferença (o quarto do Outro), onde a rasura do novo se pode entrever nas silhuetas dos autorretratos, tão nossos quanto do outro, no roçar de corpos que confluem em teias nupciais. (COSTA, 2016, p. 103)

O que acontece nessas "teias nupciais" de Virgínia e Clarice é que por meio dessas relaçóes, criam-se movimentos de escrita singulares e coletivos, de multiplicidades que não significam uma uniáo ou um afastamento total, mas um entre-laçamento, uma entre-costura que, como força, perfura as imagens majoritárias.

"Se o escritor está à margem ou afastado de sua frágil comunidade, essa situação o coloca ainda mais em condição de exprimir uma outra comunidade potencial, de forjar os meios de uma outra consciência e de uma outra sensibilidade" (DELEUZE \& GUATTARI, 1977, p.27). Assim, a escrita à margem acessa outras sensibilidades e consciências. No intertrocar com o singular dos outros, ser possível pensar nas linguagens que faltam, nas educaçóes que faltam, e transcriá-las. "É que eu não sou senão em estado potencial, sentindo que há em mim água fresca, mas sem descobrir onde é sua fonte" (LISPECTOR apud GOTLIB, 2013, p.188). Ser um estado em pleno potencial para que descubramos educaçóes em potenciais e linguagens em potenciais. E, por meio disso, existir.

Ao se permitir seguir as nervuras da madeira sobre a qual pintava, ela ao mesmo tempo cobre a superfície e chama atenção para a realidade desta, e portanto para a artificialidade de sua própria criação. Não está tentando fazer um pedaço de tela se parecer com madeira ou mármore. Não cria uma falsa superfície, mas, em vez disso, ao seguir os contornos sugeridos por uma superfície natural, faz com que essa superfície natural revele suas profundezas. (MOSER, 2011, p.347)

No ato de pintar, Clarice seguia as nervuras da madeira. Ao mesmo tempo em que cobria a superfície com imagens novas, era por meio desse movimento que revelava a própria superfície. Ao seguir as sugestôes da superfície, recriava-a em suas especificidades. Realiza-se não um movimento de imitação, mas de revelação e recriação. Dessa forma, ao pensarmos numa Transescrita da Educação com a Diferença, temos de buscar as nervuras da escola. O que a compóe como escola? Quais os movimentos do educar? Seguindo seus rastros, recompor essa superfície em busca de transcriar novas paisagens existenciais.

"Escrever como um cáo que faz seu buraco, um rato que faz sua toca. E, para isso, encontrar seu próprio ponto de subdesenvolvimento, seu próprio patoá, seu próprio terceiro mundo, seu próprio deserto" (DELEUZE \& GUATTARI, 1977, p.28-29). Em seu próprio deserto, Clarice e Virgínia montam e se desmontam. 
Salva a alma presa, salva a pessoa que se sente inútil, salva o dia que se vive e que nunca se entende a menos que se escreva. Escrever é procurar entender, é procurar reproduzir o irreproduzível, é sentir até o último fim o sentimento que permaneceria apenas vago e sufocador. Escrever é também abençoar uma vida que não foi abençoada. (LISPECTOR, 2018, p.119)

Em escrever, Clarice se atenta à vida não abençoada. Escreve o indizível, o sentir a que falta coragem e meios de dizer, e que se consegue por meio da linguagem literária. A alma presa, a vida dita inútil, ganham dimensão por meio da reflexão no espaço da literatura. A literatura abriga aquele que não tem lugar e, junto a ele, por meio de suas linguagens interrelacionadas, resistem como povo menor, como povo que falta.

"Vivo de linhas que incidem uma na outra e se cruzam e no cruzamento formam um leve e instantâneo ponto, tão leve e instantâneo que mais é feito de pudor e segredo: mal eu falasse nele, já estaria falando em nada" (LISPECTOR, 2018, p.156). O ponto móvel das linguagens em trans-e. Do sólido, passamos ao úmido da linguagem, da literatura, da educação. Linhas incidentes e dissidentes.

Tudo são bolhas e borbulhas, fervilhamento e caos. Estamos examinando a borda de um caldeirão no qual fragmentos parecem ferver e de vez em quando algum enorme vulto parece se erguer e se alçar do meio do caos, e o selvagem em nós se joga, com prazer, para a frente. (WOOLF, 2015, p.74)

Que o selvagem da escrita se apodere de nós e nos coloque à frente de um pensar outro em educaçáo, linguagem, política e realidade. Dúvidas nos movem. Educares, realidades, políticas, linguagens. Gaguejando. Delirando. "A língua é tomada por um delírio que a faz precisamente sair de seus próprios sulcos" (DELEUZE, 1997, p.15).

\section{Caminhos de transcriaçáo}

A partir das transescritas em transe de Virgínia e Clarice, propusemos transcriações outras na educação, de modo a inquietar mais do que responder, a mover-se mais do que objetivar um fim. É de tal forma que a literatura de Woolf e Lispector se movimentou, para pensarmos em educaçóes atravessadas e potencializadas pela Diferença: de maneira rastejante, à espreita, invasora, as transescritas das autoras seguiram tecendo provocações na direção de uma educação questionadora, transversalizada e que está aberta, muito mais que a fins, mas a nascimentos. Educação que reverbera entradas para outros meios de existir, não apenas para o acúmulo de saberes utilitários. Por meio das implosóes e explosóes suscitadas pelas artes literárias de Woolf e Lispector, desterritorializar conceitos sobre o educar para que, à atitude de rasgar e perfurar o que é aparentemente sólido e instituído, possam germinar e escapar novas frestas para pensar uma transescrita literária como diferença e estilo, a tatear novas páginas, telas, paisagens por vir na educação. 


\section{Referências}

CORAZZA, Sandra. (Org.). Métodos de transcriaçáo: pesquisa em educação da diferença. São Leopoldo: Oikos, 2020.

. O que se transcria em educaçáa? Porto Alegre: Doisa, 2013.

COSTA, Gilcilene Dias da. No quarto com Proust; Nietzsche, Deleuze Notas sobre o desaparecimento do leitor na literatura. In: LEMOS, Flávia Cristina Silveira. GALINDO, Dolores. (orgs). Criaçóes Transversais com Gilles Deleuze: Artes, saberes e política. Curitiba: CRV, 2016.

DELEUZE, Gilles. Crítica e Clínica. São Paulo: Editora 34, 1997.

. Mil Platôs: capitalismo e esquizofrenia, Volume 3. Rio de Janeiro: Editora 34, 1995.

Editora, 1977

; GUATTARI, Félix. Kafka: por uma literatura menor. Rio de Janeiro: Imago

GOTLIB, Nádia Batella. Clarice, uma vida que se conta. São Paulo: EDUSP, 2013

LISPECTOR, Clarice. A paixão segundo G.H. Rio de Janeiro: Rocco, 2009.

. Crônicas sobre a escrita. Rio de Janeiro: Rocco Digital, 2015.

. Todas as crônicas. Rio de Janeiro: Rocco Digital, 2018.

MOSER, Benjamin. Clarice. São Paulo: Cosac Naify, 2011

NASCIMENTO, Evando. Clarice Lispector, uma literatura pensante. Rio de Janeiro: Civilização Brasileira, 2012.

PRADO, Rafael Lovisi. Transescritas: fluxos entre o poético e o filosófico. Tese de Doutorado defendida no Programa de Pós-graduaçáo em Letras. Belo Horizonte, UFMG, 2017, $264 \mathrm{p}$.

TADEU, Tomaz; CORAZZA, Sandra; ZORDAN, Paola. Linhas de Escrita. Belo Horizonte: Autêntica, 2004.

WOOLF, Virgínia. O sol e o peixe. Belo Horizonte: Autêntica, 2015.

2013. . Profissóes para mulheres e outros artigos feministas. Porto Alegre: L\&PM,

. Um teto todo seu. Rio de Janeiro: Nova Fronteira, 2019. 